\title{
ANALISIS KEMAMPUAN KOGNITIF DAN SIKAP SISWA PADA MATERI SISTEM SARAF DI KELAS XI SMA NEGERI 2 PERCUT SEI TUAN
}

\author{
Maulida Fitri ${ }^{1 *}$, M. Yusuf Nasution ${ }^{1}$, Andriani $^{2}$ \\ ${ }^{1}$ Program Studi Pendidikan Biologi, Fakultas Matematika dan Ilmu Pengetahuan Alam, Universitas Negeri Medan, \\ Jalan Willem Iskandar Pasar V Medan Estate 20221, Sumatera Utara, Indonesia \\ ${ }^{3}$ SMAN 2 Percut Sei Tuan Jl. Pendidikan Pasar XII Bandar Klipa, Kecamatan Percut Sei Tuan, Deli Serdang, Kode Pos \\ 20371 \\ Korespondensi Author: maulidafitri14@gmail.com (Fitri)
}

\section{INFO ARTIKEL}

Histori Artikel

Received 17 Oktober 2018

Revised 5 Mei 2019

Accepted 7 Mei2019

Published 7 Juli 2019

Keywords:

cognitive ability, student attitude, nervous system

\begin{abstract}
The purpose of this study was to determine the cognitive abilities and attitudes of students in the nervous system material in class XI of SMA Negeri 2 Percut Sei Tuan Learning Year 2017/2018. The type of research used is descriptive correlational. The population in this study were students of class XI of State Senior High School 2 Percut Sei Tuan 2017/2018 Learning Year totaling 166 people. The sample in this study were 2 classes as many as 84 people in class XI Mia 3 and Mia 4 who were taken by Random sampling. Sources of data from this study are 30 multiple choice tests and 30 question attitude questionnaires. The results showed that the cognitive abilities of students about the nervous system were very good $21.42 \%$, both $51.19 \%$, good enough $13.09 \%$, less good $13.09 \%$ and very less $1.09 \%$. The results of the cognitive abilities test of students is good with an average value of 69.87 , while the cognitive abilities of students based on indicators on the material of the nervous system (1) $68.45 \%$, (2) $67.52 \%$, (3) $74,52 \%$ good category and (4) $64.28 \%$ good enough and the results of the attitude questionnaire showed students' ability both on the indicator received $71.31 \%$, valued $75.49 \%$, organized $71.32 \%$, characteristics $68.92 \%$ and sufficient both on the indicator responded to $57.93 \%$. The results of the analysis of testing the hypothesis in this study found that the cognitive abilities and attitudes of students in the nervous system material have a positive and moderate categorical relationship with $r$ count $>r$ table $(0.562>0.214)$ and $t$ count $>t$ table $(6.149>1.663)$.
\end{abstract}

\section{How to Cite:}

Fitri, M., Nasution, M.Y., Andriani. (2019). Analisis Kemampuan Kognitif dan Sikap Siswa pada Materi Sistem Saraf ii Kelas XI SMA Negeri 2 Percut Sei Tuan. Jurnal Pelita Pendidikan, 7(1), 028-034.

\section{PENDAHULUAN}

Kemampuan kognitif adalah ranah yang mencakup kegiatan mental (otak). Penampilanpenampilan yang dapat diamati sebagai hasil-hasil kegiatan atau proses memperoleh pengetahuan melalui pengalaman sendiri. Dalam ranah kognitif terdapat enam jenjang proses berpikir, dari yang terendah sampai yang tertinggi yaitu mencakup kemampuan kognitif (1) Pengetahuan (Knowlegde), (2) Pemahaman (Comprehension), (3) Penerapan (Application), (4) Analisis (Analysis), (5) Sintesis (Synthesis), dan (6) Evaluasi (Evaluation) (Sudijono, 2009). Sikap siswa terhadap pembelajaran merupakan salah satu istilah yang sering digunakan dalam mengkaji atau membahas tingkah laku manusia dalam kehidupan sehari-hari. 
Sikap yang ada pada seseorang akan membawa sikap menerima maupun menolak dalam menanggapi sesuatu hal yang ada di luar dirinya. Setiap orang memiliki sikap yang berbeda-beda terhadap suatu perangsang. Hal ini disebabkan oleh beberapa faktor yang ada pada faktor individu masing-masing seperti adanya seperti adanya perbedaan dalam bakat, minat pengalaman, pengetahuan, perasaan dan juga situasi lingkungan. Sikap digunakan untuk mengukur setiap seseorang terhadap objek tertentu hasilnya berupa kategori sikap yakni mendukung sikap positif. Sikap pada hakikatnya adalah kecendrungan berprilaku pada seseorang juga diartikan reaksi seseorang terhadap situmulus yang datang pada dirinya (Hasanudin, 2011). Sedangkan menurut Azwar (2013), sikap adalah salah satu unsur kepribadian yang harus dimiliki seseorang untuk menetukan tindakannya dan bertingkah laku terhadap suatu objek disertai dengan perasaan positif dan negatif. Berdasarkan sikap dalam ranah afektif yaitu; (1), Menerima, (2), Menanggapi, (3), Menghargai, (4) Mengorganisasikan, (5), Karakterisasi (Sagoro dan Djazari, 2011).

Menurut Maolinda, dkk (2010) kemampuan kognitif dan sikap siswa saling berhubungan. Pengetahuan juga merupakan faktor kekuatan terjadi perubahan sikap seseorang dan akan menjadi landasan terhadap pembentukan moral remaja sehingga dalam diri seseorang idealnya ada keselarasan yang terjadi antara pengetahuan dan sikap, dimana sikap terbentuk setelah terjadi proses tahu terlebih dahulu. Jadi, dalam pelaksanaan kegiatan belajar mengajar di dalam kelas diharapkan tidak hanya dapat menambah pengetahuan siswa tetapi juga dapat membangun sikap positif siswa. Pendapat diatas menyatakan bahwa yang terbentuk harus dibekali dengan pengetahuan agar seseorang memiliki moral yang baik di dalam kehidupan. Pembelajaran yang berorientasi pada pengetahuan awal akan memberikan dampak pada proses dan perolehan belajar yang memadai. Hal tersebut juga diungkapkan oleh budiarsa dkk (2016) yaitu pengetahuan awal yang dimiliki seseorang sangat berperan penting dalam pembentukan pengetahuan ilmiah selama proses pembelajaran berlangsung. Oleh karena itu, pengetahuan awal perlu digali oleh guru guna memunculkan pengetahuan yang dibentuk oleh siswa.

Sistem saraf merupakan salah satu materi pelajaran biologi yang mengandung materi kognitif yang cukup rumit, yang sulit untuk dipahami oleh siswa. Penyajian sistem saraf menuntut kemampuan guru untuk mengorganisasikan isi pelajaran sebagai persiapan untuk membangun pengetahuan dan sikap siswa. Materi ini berisi struktur dan fungsi sistem saraf, proses kerja sistem saraf, mengenali berbagai gangguan pada susunan sistem saraf (Susanti dkk, 2016).

Penelitian mengenai kemampuan kognitif siswa yang dilakukan Bachtiar dan Syamsul (2015) sangat rendah yaitu $41,29 \%$ dan $51 \%$ siswa yang tidak tuntas. Kemampuan kognitif siswa dapat berpengaruh terhadap sikap siswa. Sikap siswa dinyatakan baik pada indikator menerima dan bertanggung jawab, kurang baik pada indikator merespon, menghargai dan karakterisasi. Hasil penelitiaan Ritongga (2016) didapat bahwa nilai rata-rata tes formatif pada materi pembelajaran di SMP Abdi Negara masih dibawah nilai KKM yang ditetapkan. Hal ini dikarenakan materi sistem saraf yang sulit dipahami siswa sejalan itu kurangnya minat siswa dalam belajar dapat dilihat dari prilaku siswa ketika proses pembelajaran berlangsung tidak ada siswa yang bertanya dan mengeluarkan pendapat dan ditambah lagi tugas yang hanya dikerjakan beberapa orang saja.

Berdasarkan hasil observasi yang telah dilakukan dengan mewawancarai guru biologi kelas XI aspek kognitif yang diamati oleh guru biologi kelas XI SMA Negeri 2 yaitu dilihat dari hasil evaluasi hasil belajar siswa mencakup kemampuan pengetahuan, pemahaman, penerapan, analisis, sintesis dan evaluasi. Ditinjau dari hasil belajar siswa yang rata-rata belum memenuhi standar ketuntasan sekolah yaitu $\geq 75$. Hal dikarenakan oleh materi sistem saraf merupakan materi yang sulit karena mempelajari bagian-bagian saraf, mekanisme penghantar rangsangan, serta kelainan yang terjadi pada saraf, semua hanya berupa konsep-konsep yang tidak dapat dilihat secara langsung sehingga sulit untuk dipahami. Guru biologi memberikan metode diskusi dan presentase sesuai kurikulum 2013. Kegiatan diskusi tersebut banyak sikap siswa yang dapat diamati yaitu, partisipasi dalam kelompok, mampu menyampaikan ide dan pendapat, menghargai pendapat orang lain. Namun banyak juga siswa yang bermain-main dan tidak serius dalam dalam pembelajaran.

Berdasarkan uraian diatas Maka demikian penelitian ini bertujuan untuk mengetahui kemampuan kognitif dan sikap siswa pada materi sistem saraf di kelas XI SMAN 2 Percut Sei tuan Tahun Pembelajaran 2017/2018.

\section{METODE PENELITIAN}

Penelitian ini dilaksanakan di SMAN 2 Percut Sei Tuan Tahun Pembelajaran 2018/2017 yang beralamat di Jalan Pendidikan Pasar XII Bandar Klipa Kecamatan Percut Sei Tuan, Deli 
Serdang. Penelitian dilaksanakan pada bulan MeiJuli 2018. Populasi pada penlitian adalah seluruh siswa kelas XI MIA yang terdiri dari 4 kelas. Sampel pada penelitian dipilih dengan menggunakan Random Sampling dimana setiap kelas memiliki kesempatan yang sama untuk menjadi sampel penelitian, karena tahap penyeleksian untuk masuk ke kelas tersebut sama (Sukmadinata,
2009). Tes yang diberikan bertujuan untuk mengukur kemampuan kognitif siswa dalam mempelajari materi sistem saraf manusia. Tes disusun berdasarkan tingkat kesukaran C1 (Pengetahuan), C2 (Pemahaman), C3 (Penerapan), C4 (Analisis), C5 (Sintesis) dan C6 (Evaluasi). Jumlah tes ini adalah 30 soal dalam bentuk pilihan berganda.

Tabel 1. Kisi-kisi Tes Kemampuan Kognitif

\begin{tabular}{|c|c|c|c|c|c|c|c|c|}
\hline \multirow[t]{2}{*}{ No } & \multirow[t]{2}{*}{ Indikator } & \multicolumn{6}{|c|}{ Kriteria Soal } & \multirow[b]{2}{*}{ Jumlah } \\
\hline & & $\mathrm{C} 1$ & $\mathrm{C} 2$ & $\mathrm{C} 3$ & $\mathrm{C} 4$ & $\mathrm{C} 5$ & $\mathrm{C6}$ & \\
\hline 1 & $\begin{array}{l}\text { Mengidentifikasi stuktur, fungsi, } \\
\text { dan proses sistem saraf pada } \\
\text { manusia }\end{array}$ & 3,16 & $\begin{array}{c}7,12,1 \\
7\end{array}$ & 2,20 & & $13,9,18$ & & 10 \\
\hline 2 & $\begin{array}{l}\text { Mengaitkan stuktur, fungsi, dan } \\
\text { proses sistem saraf pada } \\
\text { manusia }\end{array}$ & 11 & & 4,10 & 26,28 & 1 & 30 & 7 \\
\hline 3 & $\begin{array}{l}\text { Menjelaskan fungsi dan proses } \\
\text { sistem saraf }\end{array}$ & & 15 & $\begin{array}{l}5,8,14 \\
24\end{array}$ & 23,25 & 19,21 & 6 & 10 \\
\hline 3. & $\begin{array}{l}\text { mengidentifikasi kelainan atau } \\
\text { gangguan pada sistem saraf } \\
\text { manusia }\end{array}$ & 27 & & 29 & 22 & & & 3 \\
\hline & Jumlah & 4 & 4 & 9 & 5 & 6 & 2 & 30 \\
\hline
\end{tabular}

Untuk mengetahui kemampuan kognitif siswa pada materi sistem saraf data yang diambil dalam penelitian ini adalah hasil dari jawaban siswa terhadap instrument tes pilihan berganda dengan rumus (Arikunto, 2008).

$\%=\frac{\text { nilaiyangdiperoleholehmurid }}{\text { skor maksimal }} \times 100 \%$

Dan instrumen non tes berupa angket sikap sebanyak 30 pernyataan dibuat atas indikator dari tinjauan pustaka mengenai sikap yaitu dari aspek: Menerima, Menanggapi, Menghargai, Organisasi, Karateristik.

Angket yang digunakan dalam penelitian ini untuk mengambil data tentang analisis sikap pada materi sistem saraf. Respon yang diharapkan dari subjek adalah menjawab pilihan yang telah ditentukan. Bentuk skala yang digunakan untuk mengukur adalah skala likert skala ini disusun dalam bentuk suatu pernyataan dan diikuti oleh 4 respon yang menunjukkan tingkatan. Masingmasing pernyataan disediakan pilihan yang menjadi alternatif dalam jawaban dan perhitungan skor menggunakan skala likert (Akdon, 2009).

Tabel 2. Kisi-Kisi Angket Sikap Siswa

\begin{tabular}{cllc}
\hline No. & \multicolumn{1}{c}{ indikator Sikap } & \multicolumn{1}{c}{ Nomor Item } & Jumlah \\
\hline 1 & Menerima (Receiving) & $1,2,3,4,5,6$ & 6 \\
\hline 2 & Menanggapi (Responding) & $7,8,9,10,11,12$ & 6 \\
\hline 3 & Menghargai (Valuing) & $13,14,15,16,17,18$ & 6 \\
\hline 4 & Mengorganisasi (Organization) & $19,20,21,22,23,24$ & 6 \\
\hline 5 & Karateristik (Characterization) & $25,26,27,28,29,30$ & 6 \\
\hline \multicolumn{5}{r}{ Jumlah } & 30 \\
\hline
\end{tabular}

Hasil angket dianalisis dengan cara menganalsiis data angket dengan mencari ratarata skor angket setiap indikator yang diteliti. Perhitungan angket data dilakukan dengan cara:
Skor indikator $=\frac{\text { jumlahskoryangdiperolehsiswa }}{\text { jumlahskorideal }} \times 100 \%$

(Sudijono, 2009). 


\section{HASIL DAN PEMBAHASAN}

Berdasarkan data yang diperoleh dari tes pilihan berganda yang berjumlah 30 soal terhadap 84 responden mengenai hasil penelitian tentang Analisis Kemampuan Kognitif dan Sikap Siswa pada Materi Sistem Saraf di Kelas XI SMA Negeri 2 Percut Sei Tuan. Maka diperoleh nilai rata-rata
69,87 (Lampiran 7). Hasil penelitian diperoleh berdasarkan nilai kemampuan kognitif siswa dalam menjawab soal yang diujikan. Data yang diperoleh dalam penelitian ini terdiri dari tes pilihan berganda yang berjumlah 30 soal terhadap 84 responden pada materi sistem saraf berdasarkan jawaban peserta tes kemampuan kognitif.

Tabel 3. Analisis Data Kemampuan Kognitif

\begin{tabular}{cccc}
\hline Rentang & Kategori & Frekuensi & Persen (\%) \\
\hline $80-100 \%$ & Sangat baik & 18 & 21,42 \\
\hline $66-79 \%$ & Baik & 43 & 51,19 \\
\hline $56-65 \%$ & Cukup Baik & 11 & 13,09 \\
\hline $40-55 \%$ & Kurang Baik & 11 & 13,09 \\
\hline $30-39 \%$ & Sangat Kurang & 1 & 1,19 \\
\hline & Jumlah & 84 & 100 \\
\hline
\end{tabular}

Dari tabel diatas yang diperoleh dari hasil kognitif siswa bahwa 18 orang siswa memiliki tingkat kemampuan kognitif yang sangat baik dengan persentase 21,42\%, 43 orang siswa memiliki baik dengan persentase 51,19\%, 11 orang siswa yang cukup baik dengan persentase 13,09\%,
11 kurang baik dengan persentase 13,09\% dan 1 orang tidak baik dengan persentase $1,19 \%$. Hal ini menunjukkan tingkat kemampuan kognitif siswa kategori baik. Kemudian analisis kebenaran siswa dalam menjawab soal pada indikator materi sistem saraf dapat dilihat dibawah ini.

Tabel 4. Persentase Kemampuan Kognitif Siswa pada Setiap Indikator

\begin{tabular}{|c|c|c|c|c|c|}
\hline No & Indikator Pembelajaran & $\begin{array}{l}\text { Skor } \\
\text { Ideal }\end{array}$ & $\begin{array}{l}\text { Skor yang } \\
\text { diperoleh }\end{array}$ & $\begin{array}{c}\text { Persentase Kemampuan } \\
\text { Kognitif }\end{array}$ & Kategori \\
\hline 1. & $\begin{array}{l}\text { Mengidentifikasi stuktur, } \\
\text { fungsi, dan proses sistem } \\
\text { saraf pada manusia }\end{array}$ & 840 & 575 & $\begin{array}{l}575 / 840 \times 100 \% \\
=68,45 \%\end{array}$ & Baik \\
\hline 2. & $\begin{array}{l}\text { Mengaitkan stuktur, } \\
\text { fungsi, dan proses sistem } \\
\text { saraf pada manusia }\end{array}$ & 588 & 397 & $\begin{array}{l}397 / 588 \times 100 \% \\
=67,52 \%\end{array}$ & Baik \\
\hline 3. & $\begin{array}{l}\text { Menjelaskan fungsi dan } \\
\text { proses sistem saraf }\end{array}$ & 840 & 626 & $\begin{array}{l}626 / 840 \times 100 \% \\
=74,52 \%\end{array}$ & Baik \\
\hline 4. & $\begin{array}{l}\text { Mengidentifikasi kelainan } \\
\text { atau gangguan pada } \\
\text { sistem saraf manusia }\end{array}$ & 252 & 162 & $\begin{array}{l}162 / 252 \times 100 \% \\
=64,28 \%\end{array}$ & Cukup Baik \\
\hline
\end{tabular}

Tabel pada materi sistem saraf diketahui bahwa persentase siswa menjawab soal pada (I) dengan benar sebesar 68,45\%, pada (2) sebesar $67,52 \%$, pada (3) sebesar 74,52\%, dan (4) sebesar $60,71 \%$. Presentase kebenaran siswa dalam menjawab soal meningkat pada indikator ke-3. Presentase kebenaran siswa dalam menjawab soal terendah terletak pada indikator 4 yaitu Mengidentifikasi kelainan atau gangguan pada sistem saraf manusia dan kebenaran siswa dalam menjawab soal tertinggi terletak pada indikator ke -3 yaitu, mengidentifikasi kelainan atau gangguan pada sistem saraf manusia. Setelah mengetahui kemampuan kognitif siswa materi sistem saraf selanjutnya akan dicari tahu sikap siswa tentang sistem saraf melalui hasil angket. Setelah angket diberi kepada siswa, maka data hasil angket tersebut dikelompokkan sesuai indikator sikap. Dapat dilihat pada tabel. 
Tabel 5. Hasil Angket Sikap Siswa

\begin{tabular}{clccc}
\hline No & Indikator Sikap & Skor ideal & Skor Indikator & Kategori \\
\hline 1. & Menerima & 2016 & 71,31 & Baik \\
\hline 2. & Menanggapi & 2016 & 57,93 & Cukup Baik \\
\hline 3. & Menghargai & 2016 & 75,49 & Baik \\
\hline 4. & Mengorganisasi & 2016 & 71,32 & Baik \\
\hline 5. & Karateristik & 2016 & 68,92 & Baik \\
\hline
\end{tabular}

Dari kelima indikator tersebut diperoleh hasil angket siswa untuk aspek sikap berdasarkan indikatornya untuk angket sikap seperti menerima memperoleh skor $71,31 \%$ yang berarti memiliki kemampuan sikap yang baik, indikator 2 menanggapi 57,93\% yang sikap cukup baik, indikator 3 menghargai 75,49\% sikap yang baik, 4 mengorganisasi $71,32 \%$ sikap yang baik, dan indikator 5 karateristik 68,92\% baik. Gambar tersebut dapat dilihat bahwa dari kelima indikator sikap terendah terletak pada indikator ke 2 yaitu menanggapi (Responding).

Dalam penelitian ini pengujian dilakukan dengan teknik analisis korelasi yaitu hubungan kemampuan kognitif $(X)$ dengan sikap siswa $(Y)$ dari hasil analisis data penelitian membuktikan bahwa terdapat hubungan yang signifikan antara kemampuan kognitif dengan sikap siswa pada materi sistem saraf di kelas XI SMA Negeri 2 Percut Sei Tuan Tahun Pembelajaran 2017/2018. Dari hasil perhitungan korelasi terdapat hubungan yang positif antara kemampuan kognitif dan sikap siswa dengan nilai koefisien harga $r_{\text {hitung }}>r_{\text {tabel }}(0,562>$ $0,214)$, dan setelah dilakukan uji $t$, didapat nilai indeks adalah presentase kontribusi variabel $X$ terhadap variabel $Y$ dan dari hasil penelitian. Berdasarkan hasil perhitungan koefisien korelasi maka didapat diperoleh bahwa indeks uji $t$ kemampuan kognitif terhadap sikap siswa sebesar 6,149 Maka koefisien korelasi antara kemampuan kognitif $(\mathrm{X}$ ) dengan sikap siswa $(\mathrm{Y})$ adalah signifikan artinya mempunyai hubungan yang dapat dikategorikan sedang.

Kemampuan kognitif berdasarkan indikator soal pada materi Sistem Saraf, indikator tertinggi terdapat pada indikator 3 menjelaskan fungsi dan proses sistem saraf, dan siswa memiliki kemampuan kognitif terendah pada indikator 4 mengidentifikasi kelainan atau gangguan pada sistem saraf. Hal ini dikarenakan pada indikator menjelaskan fungsi dan proses sistem saraf hanya mengulas penjelasan fungsi otak, menjelaskan sistem saraf pusat yang terjadi pada sistem saraf manusia. Sedangkan pada indikator mengidentifikasi kelainan atau gangguan pada sistem saraf siswa banyak merasa kesulitan pada indikator ini karena banyak siswa yang menganggap gangguan yang terjadi pada sistem saraf manusia sulit sehingga membuat tingkat pemahaman siswa menjadi kurang baik. Hal ini sesuai dengan penelitian yang dilakukan Rahayu (2016) mengenai gangguan pada sistem saraf manusia tingkat kepahaman siswa dalam menjawab soal hanya sebesar $7,16 \%$. Kesalahan konsep banyak terjadi pada materi tersebut sehingga terjadi penurunan dalam indikator ini. Adanya perbedaan kenaikan dan penurunan pada tiap indikator materi yang berhubungan dengan karakteristik, serta muatan dari tiap topik materi. Hal tersebut juga sangat berkaitan dengan modal belajar siswa seperti dengan adanya buku-buku penunjang yang dipelajarinya. Hal lain juga dapat mempengaruhi proses tingkat kepahaman siswa dan kesalahpahaman siswa, kemudian adanya metode mengajar yang tepat dan guru yang memahami materi dengan baik, sehingga mampu menyampaikan materi dengan benar, sehingga tidak ada kesalahpahaman siswa dalam memahami materi pembelajaran (Rahayu, 2016). Pengetahuan dipengaruhi oleh beberapa faktor diantaranya tingkat pendidikan. Pengetahuan yang bervariasi yang dapat disebabkan kemampuan belajar Setiap orang berbeda-beda.

Analisis sikap siswa dalam setiap indikator instrument angket pada materi Sistem Saraf yang terendah terdapat pada indikator 2 (Menaggapi). Hal ini sejalan dengan penelitian yang dilakukan Silalahi dan Aida (2016) bahwa indikator terendah sikap siswa pada materi Pencernaan Manusia terdapat pada indikator 2 menanggapi sebesar 2,6\%. Menurut Haryati (2010), pada peringkat menanggapi (responding) merupakan jawaban atau tanggapan ketika diberi stimulus, memberikan jawaban apabila ditanya serta mengerjakan dan menyelesaikan tugas yang diberikan. Hasil belajar siswa pada indikator menanggapi dilakukan sebagai bukti adanya hubungan timbal balik antara sesama teman siswa dan guru.

Sikap adalah penentu yang paling penting dalam tingkah laku manusia sebagai reaksi maka sikap selalu berhubungan dengan dua alternatif 
yaitu senang (like) atau tidak senang (dislike) untuk melaksanakan atau menjauhkannya. Dengan demikian pengetahuan mengenai sesuatu adalah awal yang mempengaruhi suatu sikap yang mungkin mengarah kepada suatu pembuatan. Setiap orang mempunyai sikap yang berbeda-beda terhadap suatu objek. Ini disebabkan oleh berbagai faktor yang ada pada individu masingmasing seperti adanya perbedaan dalam bakat, minat, pengalaman, pengetahuan, intensitas perasaan dan juga situasi lingkungan (Suharyat, 2009). Sesuai dengan yang dikemukan oleh Notoadmodjo (2010) bahwa pengetahuan yang baik akan menimbulkan sikap positif pada seseorang.

Hasil analisis data menunjukkan bahwa rata-rata skor sikap siswa adalah 70,21 yang termasuk kategori baik dan rata-rata kemampuan kognitif siswa adalah 69,87 yang juga termasuk kategori baik. Hal diatas menunjukkan bahwa kemampuan kognitif pada materi sistem saraf berhubungan dengan sikap siswa pada materi sistem saraf. Hal ini dibuktikan dengan hasil perhitungan koefisien korelasi kemampuan kognitif $(X)$ dengan hasil koefisien korelasi sikap ( $Y$ ) sebesar 0,562 yang menunjukkan bahwa terdapat hubungan yang sedang antara kemampuan kognitif dan sikap siswa pada materi sistem saraf. Penelitian yang dilakukan Rosa (2015), menunjukkan keterkaitan antara kemampuan kognitif dengan kemampuan afektif, dengan persentase keduanya sebesar $70 \%$. Menurut Sobur (2013), para ahli banyak yang menyatakan bagaimana sikap seseorang terhadap suatu objek akan mencerminkan keadaan pengetahuan orang tersebut apabila pengetahuan seseorang mengenai sesuatu yang dipahaminya tidak konsisten maka hal itu akan mempengaruhi sikap seseorang terhadap objek tersebut.

\section{KESIMPULAN}

Kemampuan kognitif siswa dalam mempelajari materi sistem saraf di kelas XI SMAN 2 Percut Sei Tuan Tahun Pembelajaran 2017/2018 dinyatakan baik dengan rata-rata nilai 69,87 . Kognitif siswa pada materi sistem saraf berdasarkan indikator (I) $68,45 \%$, indikator (2) $67,52 \%$, (3) 74,52\%, dan (4) 64,28\%. Berdasarkan jawaban keseluruhan soal ada 12 siswa kategori sangat baik, 52 siswa berkategori baik, 19 siswa yang berkategori cukup baik, dan 1 siswa berkategori kurang baik. Sikap siswa pada materi sistem saraf berkategori baik untuk indikator menerima, menghargai mengorganisasi dan karateristik. Serta berkategori cukup baik pada indikator menanggapi. Kemampuan kognitif dan sikap siswa terhadap materi sistem saraf memiliki hubungan positif dengan kategori sedang.

Bagi guru biologi agar lebih meningkatkan mutu belajar agar motivasi siswa meningkat, dan sekolah agar menyediakan fasilitas yang memadai untuk pembelajaran agar siswa lebih senang dan paham terhadap materi pembelajaran.

\section{UCAPAN TERIMA KASIH}

Penulis mengucapkan terimaksih kepada staf dan dosen FMIPA Pendidikan Biologi serta Guru SMAN 2 Percut Sei Tuan telah banyak membantu dan memberikan arahan dalam penyelesaian penelitian saya. Serta kepada temanteman dan sahabat yang banyak memberikan kesan yang luar biasa kepada penulis.

\section{DAFTAR PUSTAKA}

Akdon., R., (2009), Rumus dan Data dalam Analisis Statistik, Alfabeta, Bandung.

Azwar, S., (2013), Sikap Manusia Teori dan Pengukurannya, Yogyakarta, Pustaka Pelajar.

Budiarsa, M., Liyanti, M, P., dan Achmad, R., (2016), Pengaruh Pengetahuan Awal, Kecerdasan Emosional, dan Motivasi Belajar terhadap Hasil Belajar IPA Siswa Kelas VIII SMP Negeri 3 Parigi. e-Jurnal Mitra Sains, 4 (3) : 59-67.

Bachtiar, S., dan Syamsul, R., (2015), Hubungan antara Sikap, Kemandirian Belajar, dan Gaya Belajar dengan Hasil Belajar Kognitif Siswa, Jurnal Bioedukatika, 3 (2) : 1.5-20.

Haryati, M., (2010), Model dan Teknik Penilaian pada Tingkat Satuan Pendidikan, Jakarta, Gaung Persada Press.

Notoadmodjo, S., (2010), Ilmu Prilaku Kesehatan, PT Rineka Cipta, Jakarta.

Maolinda, N., Aat, S., dan, M., (2010), Hubungan Pengetahuan dengan Sikap Siswa terhadap Pendidikan Kesehatan Reproduksi Remaja di SMAN 1 Margahayu, Jurnal keperawatan, 1 (1) : 1-15

Rahayu, B., (2016), Analisis Deskriptif Miskonsepsi Siswa SMA pada Materi Sistem Saraf Manusia Menggunakan Teknik Certainty Response Index, Seminar Nasional 
Pendidikan dan Saintek, ISSN: 2557-533 : 929- 935.

Ritongga, N., (2016), Analisis Kesulitan Belajar pada Materi pokok Sistem Saraf Manusia di SMP Abdi Asam Jawa, Jurnal Wahana Inovasi, 5(2) : 409-415.

Rosa, O, F., (2015), Analisis Kemampuan Siswa Fisika Kelas $X$ pada Ranah Kognitif, Afektif, dan Psikomotorik, Jurnal Fisika dan Pendidikan Fisika, 1(2) : 24-28.

Sagoro, E., dan Djazari, M., (2011), Evaluasi Prestasi Belajar Mahasiswa Program Kelanjutan Studi Jurusan Pendidikan Akuntansi ditinjau dari IPK D3 dan Asal Perguruan Tinggi, Jurnal Pendidikan Akuntansi Indonesia, IX (2) : 103-112.

Silalahi, H, F., dan Aida, F, S., (2016), Analisis Kemampuan Kognitif, Sikap dan Perilaku pada Siswa Tentang Kesehatan Pencernaan Manusia Kelas XI SMA N 5 Medan, Jurnal Pelita Pendidikan, 4(3) : 31-39.

Sobur, A., (2013), Psikologi Umum, Bandung, Pustaka Setia.

Sudijono, A., (2009), Evaluasi Pendidikan, Rajawali Pers, Jakarta.

Susanti., Dian, L., dan Sri, M., (2016), Pengembangan Perangkat Blended Learning Sistem Saraf Manusia untuk Meningkatkan Keterampilan Berpikir Kritis, Journal of Innovative Science Education,2 (2) : 83-93.

Suharyat, Y., (2009), Hubungan antara Sikap, Minat dan Perilaku Manusia. e- Journal Unisma. 1(1): 1-17.

Sukmadinata., (2009), Metodologi Penelitian, PT Bumi Aksara, Jakarta. 